\title{
Understanding what is what in marine shrimp fisheries
}

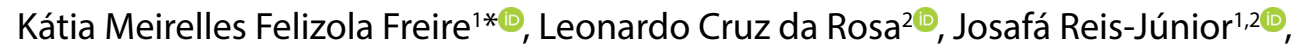 \\ Thaíza Maria Rezende da Rocha Barreto 1,3 (1)
}

\begin{abstract}
1 Universidade Federal de Sergipe, Departamento de Engenharia de Pesca e Aquicultura (Av. Marechal Rondon, s/n - Jardim Rosa Elze, São Cristóvão - Sergipe - Brazil, 49100-000)

${ }^{2}$ Universidade Federal Rural de Pernambuco, Programa de Pós-graduação em Biometria e Estatística Aplicada (PPGBEA) (Rua Dom Manoel de Medeiros, s/n - Dois Irmãos, Recife - Pernambuco - Brazil, 52171-900)

${ }^{3}$ Universidade Federal de São Paulo (UNIFESP), Laboratório de Ciências da Pesca (LabPesca), Instituto do Mar (IMar) (Campus Baixada Santista, Rua Carvalho de Mendonça, 144 - Encruzilhada, Santos - São Paulo - Brazil,11070-100)

*Corresponding author: kmffreire2018@gmail.com
\end{abstract}

\section{Abstract}

Shrimps are the main fishery resource in marine waters off Sergipe (northeastern Brazil), where they are landed in three categories: 'espigão', 'escolha' and 'pistola'. The objective of this study was to identify which species are landed in each category, relating to the perception of stakeholders, and to analyze their effect on the interpretation of historical catch statistics. Samples of 3kg were collected monthly for each category before landing in Aracaju (May/2015-May/2016) to identify the shrimp species caught. All specimens were identified, measured (carapace length - mm) and weighed (total weight - g), and had their sex determined. We interviewed attendees of two meetings promoted by the Programa de Monitoramento Participativo do Desembarque Pesqueiro in Aracaju and Pirambu, the two main ports where shrimp catches are landed in Sergipe, and asked for their perception of shrimp species included in each category. Finally, we used all shrimp catch data available for Sergipe in a national reconstructed database to improve the reconstruction based on the species composition estimated here for the main shrimp species. The analysis of each category indicated the presence of commercially important species (Xiphopenaeus kroyeri, Penaeus subtilis, Penaeus brasiliensis, and Penaeus schmitti), and also species of no local commercial interest: Exhippolysmata oplophoroides, Nematopalaemon schmitti, Rimapenaeus constrictus, and Sicyonia dorsalis. The category 'espigão' was dominated by X. kroyeri (94.2\%) and 'escolha' by P. subtilis (95.3\%). 'pistola' was mostly P. subtilis (78.3\%), almost all of them females, followed by P. schmitti (12.3\%). The perception of stakeholders was correct for 'espigão' and 'escolha', but not for 'pistola', as 38\% of the respondents classified it as 'camarão-

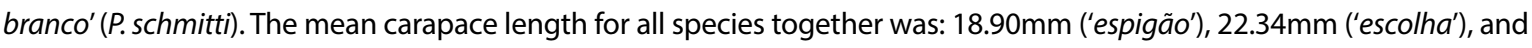
$30.96 \mathrm{~mm}$ ('pistola'). Decreasing catches of $X$. kroyeri, P. subtilis and P. schmitti in the last years raise concern.

Descriptors: Penaeidae, Xiphopenaeus, Penaeus, Commercial fishery.

\section{INTRODUCTION}

Shrimp fishery is one of the most important in Brazil due to their high market value. However, artisanal and industrial catches for shrimps amounted to only $5-12 \%$ of total catches for the period $1950-2010$

Submitted on: 1/April/ 2020

Approved on: 26/May/2020

Associate Editor: Francesc Maynou

Editor: Rubens M. Lopes

cC) (i) 2020 The authors. This is an open access article distributed under the terms of the Creative Commons license. (based on the reconstructed database compiled by Freire et al., 2015). The families of shrimps with the highest economic interest along the Brazilian coast are Penaeidae and Solenoceridae (Dias-Neto, 2011). Among penaeids, the following species are caught: Xiphopenaeus kroyeri (Heller, 1862), Penaeus subtilis (Pérez Farfante, 1967), Penaeus brasiliensis Latreille, 1817, Penaeus paulensis (Pérez Farfante, 1967), Penaeus schmitti (Burkenroad, 1936), and Artemesia longinaris (Bate, 1888), with higher or lower production in different regions along the coast. On the other 
hand, solenocerids are represented by Pleoticus muelleri (Bate, 1888), which is restricted to southeasternsouthern Brazil. Dias-Neto (2011) presented a proposal for the management of five species of penaeids that were included in the Annex II of the Executive Order of the Ministry of Environment (Instrução Normativa MMA n. 5/2004) as overexploited or threatened of overexploitation in Brazilian waters (MMA, 2004a): $X$. kroyeri, P. subtilis, P. paulensis, P. brasiliensis, and $P$. schmitti. A management plan should be put into place within a maximum period of five years after this Executive Order was issued for all species listed in its Annex II. However, a more recent assessment by Boos et al. (2016) indicated that, except for P. subtilis, which was considered of 'Least Concern', all other penaeids listed in the Annex II received the status of 'Data Deficient'.

Any fishery management plan to be implemented in Brazilian waters has to deal firstly with the nomenclatural issue that was pointed out by Dias-Neto (2011) and also by Freire et al. (2015): shrimp catches (and also for many other groups) are reported by common name. In the case of shrimps, names such as 'camarão pequeno' (small shrimp), 'camarão médio' (medium shrimp) and 'camarão grande' (large shrimp) are commonly used. Depending on the Brazilian state, the correspondence between common and scientific name varies. For example, for the states of Piauí, Pernambuco, Sergipe and Bahia, all in northeastern Brazil, Dias-Neto (2011) used the following equivalence: 'camarão grande' = 'camarão-branco' = Penaeus schmitti, 'camarão médio' = 'camarão-rosa' = Penaeus subtilis, and 'camarão pequeno' = 'camarão-espigão' = 'camarão-sete-barbas' = Xiphopenaeus kroyeri. Due to the uncertainty in the attribution of common names to the correct species, Dias-Neto (2011) suggested to use a value of $10,900 \mathrm{t}$ as maximum sustainable yield (MSY) for all shrimp species altogether in northeastern Brazil, which was equivalent to the mean catch of the last two years for the period 1987-2006 for which data were available at that time. However, management of shrimp stocks has to consider the species composition, as each species has its own population parameters.

Official catch statistics by species for each Brazilian state came to an end in 2007 (IBAMA, 2007). For 2008-2011, national bulletins presented only total catch for each state, with no detail on production by species (MPA, 2009 a, b; MPA 2012), and catch for the country as a whole detailed by species. However, local initiatives in some states, including the state of Sergipe, in northeastern Brazil, were able to maintain a continuous collection system of catch statistics from 2010 to 2016 (Thomé-Souza et al., 2012, 2013, 2014a,b; Araújo et al., 2016). The correspondence between common and scientific names for Sergipe is also confusing and changed through time: all these references considered that 'camarão-espigão' = 'camarão-sete-barbas' $=X$. kroyeri and 'camarão-pistola' $={ }^{\prime}$ camarão-branco' $=P$. schmitti. A third category locally known as 'escolha' was initially attributed to $X$. kroyeri and later to various medium-sized shrimp species. Finally, a fourth category, 'camarão-rosa' was initially attributed to Penaeus spp. (P. schmitti excluded) and later to $P$. subtilis and P. brasiliensis. Data for 2015 and 2016 are not published yet and the collection system was interrupted in late 2016 . The collection system was resumed later on under a new direction, but its data are not publicly available. We conducted this study aiming at analyzing the taxonomic composition in each of the categories 'espigão', 'escolha' and 'pistola' landed in the state of Sergipe, comparing to the perception of local stakeholders. Based on these results, catches reported for shrimps by common name in national and local bulletins were split into the species effectively caught in Sergipe.

\section{MATERIAL AND METHODS}

Samples of $3 \mathrm{~kg}$ each were collected monthly for each category separated manually by fishers onboard, based on shrimp size ('espigão' = small, 'escolha' = medium, and 'pistola' = large), before landing in the Port of Aracaju, from May 2015 to May 2016 (fishing ground: $10^{\circ} 44^{\prime} 16^{\prime \prime} \mathrm{S} 36^{\circ} 51^{\prime} 22^{\prime \prime} \mathrm{W}$ to $11^{\circ} 31^{\prime} 09^{\prime \prime} \mathrm{S}$ $37^{\circ} 30^{\prime} 42^{\prime \prime} \mathrm{W}$; Figure 1). No sample was collected during the closed seasons, which correspond to April $1^{\text {st }}$ to May $15^{\text {th }}$ and December $1^{\text {st }}$ to January $15^{\text {th }}(\mathrm{MMA}$, 2004b). Artisanal shrimp trawlers are $8-13 \mathrm{~m}$ long and operate with double nets along the coast of the state of Sergipe. Each sample was taken to the Laboratório de Ecologia Pesqueira (LEP) of the Departamento de Engenharia de Pesca e Aquicultura (DEPAQ) at the Universidade Federal de Sergipe (UFS) and kept frozen until processing. Within each category, all specimens in the samples were identified, measured (carapace length - $\mathrm{CL} ; \mathrm{mm}$ ), and weighed (total weight - TW; 


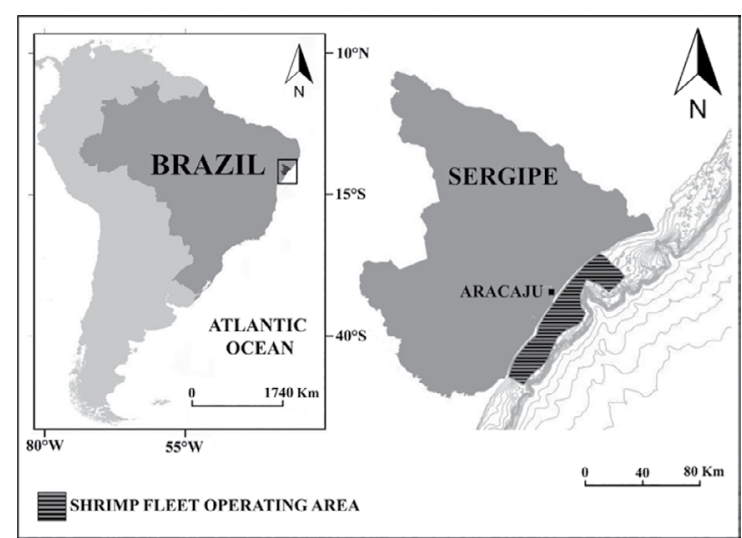

Figure 1. Map showing the approximate location of the Fishing Port of Aracaju and the shrimp fleet oparating area in the coast of the state of Sergipe.

g). All individuals were sexed based on the external morphology (thelycum in females and petasma in males). For identification of the shrimps, Costa et al. (2003) and Teodoro et al. (2016) were used. The scientific species names and respective authorships used throughout this paper followed the World Register of Marine Species (marinespecies.org). The English common names corresponded to the ASFIS List of Species for Fishery Statistics Purposes (www.fao.org) and to the SeaLifeBase common name (www.sealifebase.org) in case there was no name available in the ASFIS List.

The percentage of each species within each category ('espigão', 'escolha' and 'pistola') was then estimated for the entire period and also by month. The mean carapace length $(\mathrm{CL})$ for each species was calculated within each of these categories. For the main species within each category, we calculated the sex ratio and tested for statistical significance using the chisquare test with correction for continuity (Zar, 2010). Additionally, the mean carapace length $(\mathrm{CL})$ and total weight (TW) were calculated for all shrimps within each category, independently of the species included in that category. These two variables were compared among categories using the Kruskal-Wallis rank sum test and the posterior Wilcoxon test after the hypotheses of normality (using the Kolmogorov-Smirnov test) and homocedasticity (using the Bartlett test) were rejected (Zar, 2010). All tests were performed using a significance level of $5 \%$. We also prepared carapace length distributions for each sex and main species separately, within each category, in order to analyze the existence of patterns among categories.
In order to better understand the perception of local fishing boat owners and skippers, fishers and food processors about which species are included in each category, we interviewed attendees of two meetings promoted in 2016 by the Programa de Monitoramento Participativo do Desembarque Pesqueiro (PMPDP), which are called 'devolutivas' (meetings with local fishers and other stakeholders, where collected catch statistics are discussed). For this study, our group participated in the meetings taking place in the municipalities of Aracaju and Pirambu, where the shrimp fleets are based. Both fleets operate in the same fishing ground with similar boat size and double nets. For this, we used a small questionnaire where the respondents were asked to point out which shrimp species were included in each category ('espigão', 'escolha' and 'pistola'). Thus, we could compare the shrimp species composition as seen in the general literature dealing with catch statistics and the perception of local stakeholders with our results from the samples collected within each category landed in Sergipe.

The proportion of each shrimp species within each category estimated here for 2015-2016 was used to split catches reported for Sergipe in national or local statistical bulletins for 1962-2015, and available in the database compiled by Freire et al. (2015). For periods where no landing data was reported (1965, 1970 and 2008-2009), a linear trend was used to interpolate missing values (Freire et al., 2015).

\section{RESULTS}

The analysis of each category of shrimps caught in the state of Sergipe indicated the presence of commercially important species (Xiphopenaeus kroyeri, Penaeus subtilis, Penaeus brasiliensis and Penaeus schmitti), and also species of no local commercial interest: Exhippolysmata oplophoroides (Holthuis, 1948), Nematopalaemon schmitti (Holthuis, 1950), Rimapenaeus constrictus (Stimpson, 1871), and Sicyonia dorsalis Kingsley, 1878. The category 'espigão' was dominated by $X$. kroyeri throughout the period analyzed (94.2\%; Table 1). Even though there was monthly variation in the participation of this species, it was always equal or higher than $83 \%$ of the total catch in weight. Exhippolysmata. oplophoroides, N. schmitti, R. constrictus and S. dorsalis were almost exclusively present in 'espigão' due to their small size (Table 1). The category 'escolha' was mainly represented 
Table 1. Mean percentage of total weight for each shrimp species landed in the Fishing Port of Aracaju (Xiphopenaeus kroyeri, Penaeus subtilis, Penaeus brasiliensis and Penaeus schmitti), in the state of Sergipe, by size category from May 2015 to May 2016. The percentage range is presented within parentheses. 'Others' include Exhippolysmata oplophoroides (Cock shrimp), Nematopalaemon schmitti (Whitebelly prawn), Rimapenaeus constrictus (Roughneck shrimp) and Sicyonia dorsalis (Lesser rock shrimp).

\begin{tabular}{lccccc}
\hline $\begin{array}{l}\text { Category } \\
\text { (size) }\end{array}$ & $\begin{array}{c}\text { X. kroyeri } \\
\text { Atlantic seabob }\end{array}$ & $\begin{array}{c}\text { P. subtilis } \\
\text { Southern brown } \\
\text { shrimp }\end{array}$ & $\begin{array}{c}\text { P. brasiliensis } \\
\text { Redspotted shrimp }\end{array}$ & $\begin{array}{c}\text { Pouthern white } \\
\text { shrimp }\end{array}$ & Others \\
\hline 'Espigão' & 94.2 & 4.5 & 0.1 & 0.03 & 1.2 \\
(Small size) & $(83.0-98.2)$ & $(1.8-10.8)$ & $(0.0-0.5)$ & $(0.0-0.5)$ & $(0.0-8.8)$ \\
'Escolha' & 0.2 & 95.3 & 2.5 & 2.0 & 0.01 \\
(Medium size) & $(0.0-0.5)$ & $(82.8-100.0)$ & $(0.0-15.0)$ & $(0.0-7.2)$ & $(0.0-0.1)$ \\
'Pistola' & 0.0 & 78.3 & 9.4 & 12.3 & 0.0 \\
(Large size) & $(0.0-0.0)$ & $(32.2-94.0)$ & $(0.0-59.5)$ & $(2.6-32.0)$ & $(0.0-0.0)$ \\
\hline
\end{tabular}

by $P$. subtilis (95.3\%). However, there are some monthly variations in this category. In November, e.g., $P$. brasiliensis reached a proportion much higher than in other months (about 15\%) within this category. Penaeus schmitti had a low participation around 2\%, but reached about $7 \%$ in January and May. Finally, 'pistola' was mostly represented by $P$. subtilis (78.3\%), followed by P. schmitti (12.3\%) (Table 1). Note that $P$. subtilis and $P$. brasiliensis together represented usually more than $86 \%$ of the 'pistola' catch. Only in January, their participation decreased to about $68 \%$ and the contribution of $P$. schmitti increased to $32 \%$.

The number of stakeholders (fishers, boat masters and processors) attending the 'devolutivas' in 2016 was low and, thus, we were able to obtain answers to our questionnaire from only 13 shrimp fishery related-men and -women. We did not find information on the total number of stakeholders involved in shrimp fisheries in Sergipe. Araújo et al. (2016) estimated that around 552 fishers operate in larger motorized boats (locally named as 'lanchas') in this state, but these include shrimp trawlers, gillnetters and those targeting tuna and tuna-like fishes. Even though the exact number of stakeholders is not known, the representativeness of this sample is certainly low, but at least they provide a sense of local perception that can be added to what is currently found in the literature. The answers to the questionnaires indicated that about $69 \%$ of them considered 'espigão' as small shrimp, with low market value, which corresponds to X. kroyeri. A total of 31\%, on the other hand, explicitly associated it to 'sete-barbas' (X. kroyeri). For the category 'escolha', 54\% of the respondents associated it to 'camarão-rosa' (P. subtilis and P. brasiliensis) and $23 \%$ to medium-sized shrimps (no species name mentioned). Finally, 'pistola' was perceived as large shrimp by $46 \%$ of the respondents and 'camarão-branco' (P. schmitti) by $38 \%$ of them. The remaining respondents considered some degree of overlapping between categories. Thus, the perception of fishery-related workers corresponds to the species composition analyzed in this study for the majority of the interviewees. However, there is a high percentage (38\%) of them who associated 'pistola' to $P$. schmitti and this may pose problems in the analysis of catch statistics, as they are represented mostly by $P$. subtilis.

In general, the mean carapace length of each shrimp species ( $X$. kroyeri, $P$. subtilis, $P$. brasiliensis and $P$. schmitti) included in each category ('espigão', 'escolha' and 'pistola') is similar (Table 2). No statistical test was applied, as the sample size was very small for some species. Penaeus schmitti presented the largest maximum carapace length among all specimens $(52.50 \mathrm{~mm})$, but within the category 'pistola', the mean carapace length was higher for $P$. brasiliensis (Table 2). It is also clear the increase in mean carapace length from the category 'espigão' $(18.90 \mathrm{~mm})$ to 'escolha' $(22.34 \mathrm{~mm})$ and to 'pistola' $(30.96 \mathrm{~mm})$, as indicated by the statistical tests presented in Table 3. Similarly, mean total weight statistically increased from 'espigão' $(4.21 \mathrm{~g})$ to 'escolha' (8.64g) and to 'pistola' (20.03g) (Table 3). Looking at the size distribution into more detail, one can see that 'espigão' is basically $X$. kroyeri, with higher abundance of females (1.5F:1 M; $X^{2}=127.95$; $p<0.001)$, 'escolha' corresponds to $P$. subtilis, here with slightly higher abundance of males $(0.9 \mathrm{~F}: 1 \mathrm{M}$; $X^{2}=4.83 ; p=0.016$ ), and 'pistol $a^{\prime}$ is associated basically with females of $P$. subtilis (469F: $1 \mathrm{M} ; X^{2}=470.00$; $p<0.001$ ) (Figure 2). 
Table 2. Mean carapace length ( $\mathrm{mm}$ ) of each main shrimp species landed by size category in the Fishing Port of Aracaju (Xiphopenaeus kroyeri, Penaeus subtilis, Penaeus brasiliensis and Penaeus schmitti), in the state of Sergipe, from May 2015 to May 2016. The minimum and maximum carapace length is presented within parentheses; ' $n$ ' represents sample size.

\begin{tabular}{lcccc}
\hline $\begin{array}{l}\text { Category } \\
\text { (size) }\end{array}$ & $\begin{array}{c}\text { X. kroyeri } \\
\text { Atlantic seabob }\end{array}$ & $\begin{array}{c}\text { P. subtilis } \\
\text { Southern brown shrimp }\end{array}$ & $\begin{array}{c}\text { P. brasiliensis } \\
\text { Redspotted shrimp }\end{array}$ & $\begin{array}{c}\text { P. schmitti } \\
\text { Southern white shrimp }\end{array}$ \\
\hline 'Espigão' & 19.33 & 17.99 & 21.05 & 18.90 \\
(Small) & $(8.11-31.57)$ & $(12.75-26.43)$ & $(20.73-21.37)$ & $(18.90-18.90)$ \\
$\mathrm{n}$ & 4,199 & 136 & 2 & 1 \\
'Escolha' & 21.25 & 22.25 & 25.56 & 26.31 \\
(Medium) & $(18.65-24.01) 7$ & $(13.98-40.71)$ & $(20.75-31.49)$ & $(21.51-34.80)$ \\
$\mathrm{n}$ & - & 2,798 & 45 & 44 \\
'Pistola' & $(-)$ & 30.80 & 33.91 & 30.20 \\
(Large) & 0 & $(20.98-45.66)$ & $(25.93-46.43)$ & $(22.41-52.20)$ \\
$\mathrm{n}$ & & 940 & 85 & 136 \\
\hline
\end{tabular}

Table 3. Mean carapace length $(\mathrm{mm})$ and total weight $(\mathrm{g})$ of shrimps (independently of the species) included in each category ('espigão', 'escolha' and 'pistola') landed in the Fishing Port of Aracaju, in the state of Sergipe, and sampled from May 2015 to May 2016. The values of D for the Kolmogorov-Smirnov (normality test), $\chi^{2}$ for the Bartlett test (homocedasticity), $\chi^{2}$ for the Kruskal-Wallis rank sum test (comparing length and weight among categories), and $W$ for Wilcoxon test (comparing length and weight between each two categories) are presented together with their respective p-values.

\begin{tabular}{lcc}
\hline Category (size) & Carapace length $(\mathrm{mm})$ & Total weight $(\mathrm{g})$ \\
\hline 'Espigão' (Small) & 18.90 & 4.21 \\
'Escolha' (Medium) & 22.36 & 8.67 \\
'Pistola' (Large) & 30.96 & 20.03 \\
Kolmogorov-Smirnov & $0.2405(p<0.001)$ & $0.2533(p<0.001)$ \\
Bartlett & $323.1(p<0.001)$ & $2,223.7(p<0.001)$ \\
Kruskal-Wallis & $8,643.6(p<0.001)$ & $9,557.9(p<0.001)$ \\
Wilcoxon test: & & $1.5 \times 10^{6}(p<0.001)$ \\
'Espigão' vs 'Escolha' & $5.1 \times 10^{6}(p<0.001)$ & $0(p<0.001)$ \\
'Espigão' vs 'Pistola' & $0(p<0.001)$ & $5.8 \times 10^{4}(p<0.001) \mathrm{w}$ \\
'Escolha' vs 'Pistola' & $224(p<0.001)$ & \\
\hline
\end{tabular}

In the bulletins available with fishery statistics for the state of Sergipe, for the periods 1962-1984 and 1990-1995, catches were reported as marine shrimp ('camarão de mar'). For 1985-1989 and 1996-2007, catches were reported only for Atlantic seabob ('camarão sete-barbas') and southern white shrimp ('camarão branco'). Only from 2010 onwards more detailed information on species composition was provided, but still by common name. When the species composition described here was used to split total catches reported by common name into scientific name for the state of Sergipe, one can see that most of the catches were represented by $X$. kroyeri, followed by $P$. subtilis (Figure 3).

Even though shrimp fisheries began in the state of Sergipe in 1962, their catches combined were very low and added to an annual average of 57 metric tons until 1979 (28-114 metric tons). Catches started to become significant only from 1980 onwards (Figure 3). Overall, catches for $X$. kroyeri corresponded to $77 \%$ of total catches extracted in 1962-2015 and 19\% to P. subtilis. Each of the remaining species had proportions of $3 \%$ or lower. A closer look at the time series for these two top shrimp species indicate that catches increased sharply until 1987 and decreased afterwards, reaching lower values in 1993 (Figure 3A). After that year, another increase was observed and the highest catch for $X$. kroyeri for the entire time series was observed in 1998 (1,696 metric tons). After 1998 , catches started to continuously decrease except for a slight increase in the last five years. In general, the same pattern was observed for $P$. subtilis and $P$. schmitti, but the highest catch values were 

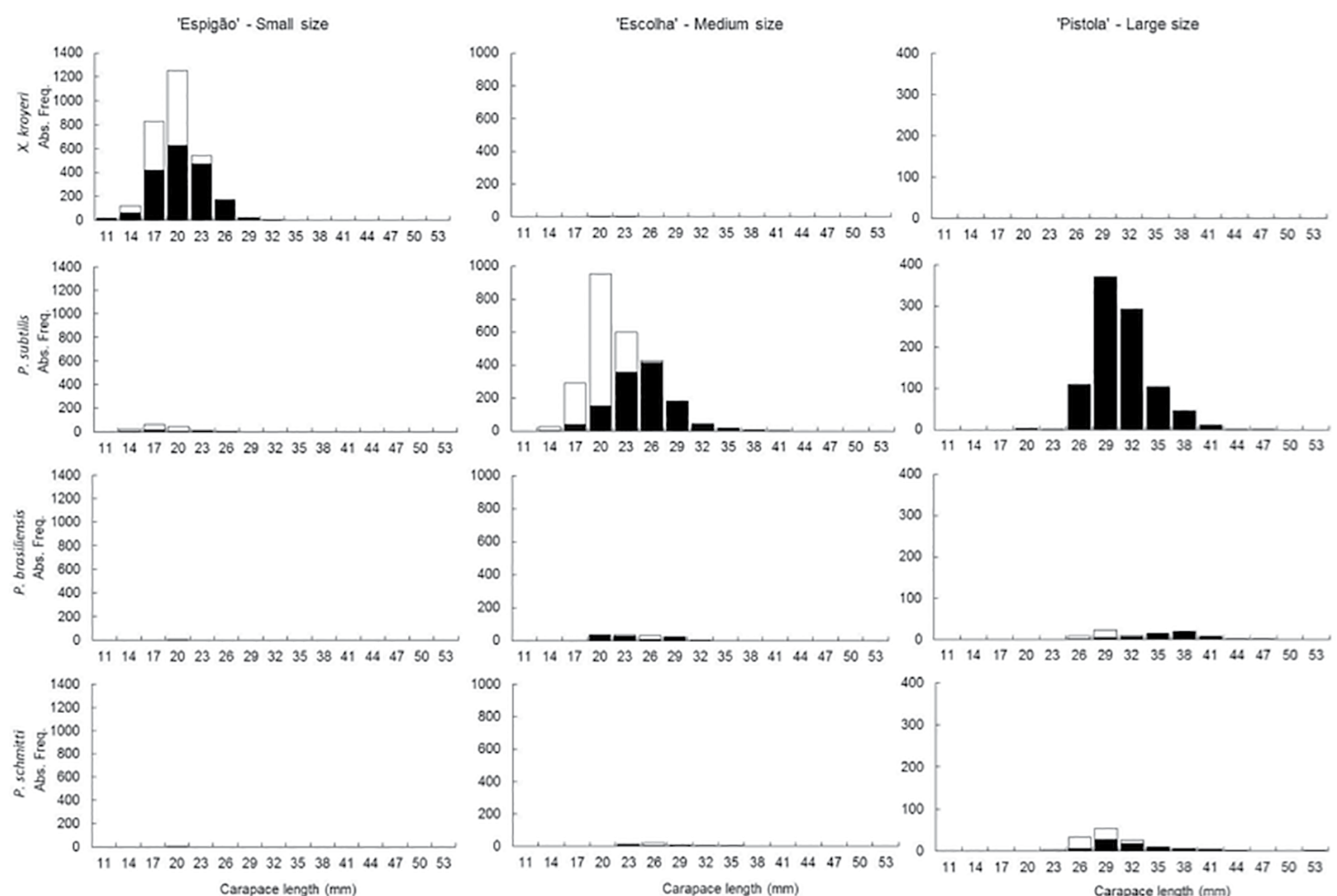

Figure 2. Frequency distribution of carapace length for males (white columns) and females (black columns) of Xiphopenaeus kroyeri, Penaeus subtilis, Penaeus. brasiliensis and Penaeus. schmitti landed in the Fishing Port of Aracaju, in the state of Sergipe, from May 2015 to May 2016, within each category ('espigão', 'escolha' and 'pistola'). Note the use of different scales for the Y-axes among categories.
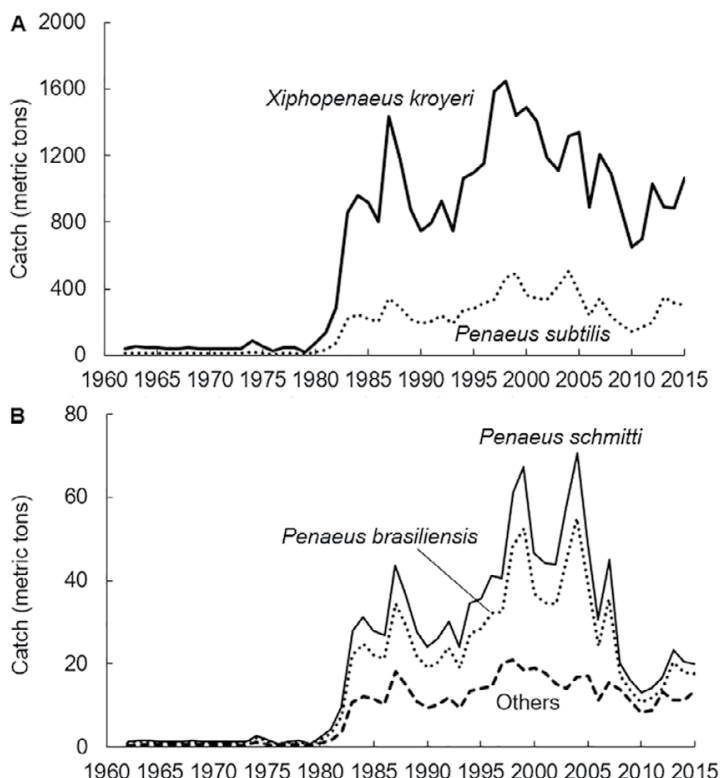

Figure 3. Time series of catches for two species that represented $95 \%$ of the total catch of shrimps in the coast of the state of Sergipe from 1962 to 2015. A. Remaining catches are attributed to P. schmitti, P. brasiliensis and others (include Exhippolysmata oplophoroides, Nematopalaemon schmitti, Rimapenaeus constrictus and Sicyonia dorsalis); B. Reconstruction based on data compiled by Freire et al. (2015) and using the species composition estimated in this study. Note the use of different scales for the $\mathrm{Y}$-axes in $\mathbf{A}$ and $\mathbf{B}$. observed in 2004: 511 and 74 metric tons, respectively (Figure 3 ).

\section{DISCUSSION}

Our results indicated that the separation of each category 'espigão', 'escolha' and 'pistola' in Sergipe was clearly based on size, as commonly stated. Additionally, we were able to report that the mean size within one category was very similar among species. However, the composition usually assumed for shrimps in northeastern Brazil cannot be used throughout all states of this region for all these three categories. In Sergipe, as expected, 'espigão' corresponds mostly to $X$. kroyeri (with higher abundance of females) and 'escolha' to P. subtilis (with slightly higher abundance of males). However, the category 'pistola', usually attributed to $P$. schmitti, corresponds in fact to P. subtilis ( $99.8 \%$ females). This has some important management implications, as 'pistola' is the category with the highest market value and at the same time comprises mainly larger females of $P$. subtilis with higher expected reproductive capacity. If any initiative is taken to increase landings of 'pistola', 
e.g., all stakeholders should be aware they are in fact increasing pressure mainly on females of $P$. subtilis, as only $12.3 \%$ of the catch for 'pistola' were attributed to $P$. schmitti. This is contrary to the current perception of local stakeholders, as evidenced in the questionnaires, and also in literature (see, e.g., Dias-Neto, 2011). This lower contribution of $P$. schmitti could also be related to its lower abundance, as found in a survey conducted in Sergipe from 2013 to 2014 (Santos et al., 2017).

Nomenclatural issues in catch statistics have been known for a long time (Freire and Pauly, 2005), but this has to be continuously monitored to allow for checking possible changes in the abundance of different shrimp species. The reconstruction process for catches off Sergipe performed by Freire and Araújo (2016), e.g., erroneously considered 'camarão-bran-

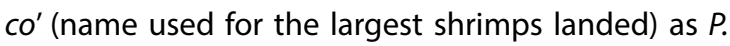
schmitti, as this was the only information available at that time. Nevertheless, these largest shrimps are mainly represented by $P$. subtilis in Sergipe. In relation to neighbor states, we found that 'camarão-rosa' represents the second largest shrimp catch in the state of Bahia (IBAMA, 1997), as it was observed in Sergipe (here represented mainly by $P$. subtilis, but also by $P$. brasiliensis). However, for the state of Alagoas, IBAMA (2007) points out that 'camarão-branco' (P. schmitti) is responsible for the second largest shrimp catches after $X$. kroyeri. This information should be reviewed considering the proximity and overlapping of fishing grounds between the states of Alagoas and Sergipe. Based on our results, it is expected that $P$. subtilis (together with a smaller proportion of $P$. brasiliensis) is the second main species landed in Alagoas. We hope that local scientists revisit the species composition of landings to improve the reporting system of catch statistics locally and hence nationally.

Decreasing catches of $X$. kroyeri in 2015 to $65 \%$ of the catch obtained in 1998 raise concerns, even though it continues to be the main fishery resource in the state of Sergipe. Reduced catches observed for P. subtilis and P. schmitti from 2004 to $55 \%$ and $27 \%$ in 2015, respectively, are even worse considering that their prices per kilogram correspond to 2.0 and 2.5 times the price of $X$. kroyeri (R\$ 7.19 or US\$ 2.93 in 2014; Araújo et al., 2016).
The first legislation aiming at controlling shrimp fisheries was Executive Order (Portaria) n. 12/1977/ SUDEPE (Superintendência do Desenvolvimento da Pesca), which established that the area corresponding to $4 \mathrm{~nm}$ (nautical miles) off the coast could not be fished by boats of above 4 gross tonnage in the state of Bahia. In 1983, a protected area corresponding to the limit of $3 \mathrm{~nm}$ was established for the state of Sergipe. In 2004, the exclusion area was decreased to $2 \mathrm{~nm}$ (MMA, 2004b). Besides, closed seasons were established from December $1^{\text {st }}$ to January $15^{\text {th }}$ and from April $1^{\text {st }}$ to May $15^{\text {th }}$ (MMA, 2004b). Additionally, a minimum mesh size of $28 \mathrm{~mm}$ was established in the cod-end for marine areas in northeastern Brazil (see Franco et al., 2009 for a more comprehensive list of legislation documents related to shrimp fisheries). Even though a series of protection measurements were in place, it did not avoid the inclusion of all three targeted shrimp species mentioned here in the Annex II of the Executive Order n. 5/2004 of the Ministry of Environment (MMA, 2004a) for being overexploited or threatened of overexploitation. However, Boos et al. (2016) later listed all these species as 'Data Deficient', with the exception of $P$. subtilis, which was considered of 'Least Concern'. Indeed, specific data related to the population dynamics of these fish stocks have been obtained only recently for the state of Sergipe (see, e.g., Santos et al., 2017; Reis Jr. et al., 2019; Freire et al., 2019; Carvalho Santos et al., 2020).

Thus, one should agree that data are still deficient in this state and do not allow for proper assessment of local stocks of each species. Moreover, there is uncertainty in the use of current proportions of different shrimp species for the first years of the reconstruction of the catch statistics, as we are not sure if the category 'pistola' could have comprised higher proportion of $P$. schmitti in the earliest years of the time series of catch data than in the last ones. This study sets a baseline from which changes in catch composition can be monitored in the future. We suggest that the same analysis of composition is extended to other states in northeastern Brazil to better understand the categorization of shrimps when landed. We hope our results contribute to decrease the information gap pointed out by Teixeira et al. (2019) related to the low number 
of publications available for developing countries on the management and conservation aspects of shrimp fisheries. Here we were able to call attention to the fact that any management and conservation initiative has to begin with the proper association of catches to the correct species. Only then, research efforts can be directed to produce information on the population dynamics of each of those species, decreasing the level of 'data deficiency'. This is particularly true for the largest shrimps landed in Sergipe, which have the highest market value, but are perceived as a different species both by local stakeholders as well as in the literature available. Decreasing catches in the last ten years for the main commercial shrimp species in Sergipe add more pressure on producing information about the dynamics of these stocks.

\section{ACKNOWLEDGEMENTS}

We would like to thank Diógenis Lopes for helping to collect all shrimp samples used in this study; the support of Projeto de Monitoramento Participativo de Desembarque Pesqueiro (PMPDP) and Fundação de Apoio à Pesquisa e Extensão de Sergipe (FAPESE) (Grant numbers 2600.0094374.14.4 and 2600.0099827.15.4); to Aline A. S. Dias, Ana Cláudia Gaspar and Sandra Lima for helping with sample processing; and to Robson Rosa for preparing the map of the study area. J. Reis Júnior and T. M. R. R. Barreto thank FAPESE/PMPDP for their scholarships.

\section{AUTHOR CONTRIBUTIONS}

Kátia M. F. Freire: Conceptualization, Data curation, Formal Analysis, Funding acquisition, Investigation, Methodology, Writing - original draft

Leonardo C. da Rosa: Conceptualization, Methodology, Investigation, Writing - review \& editing

Josafá Reis Jr.: Conceptualization, Formal Analysis, Methodology, Investigation, Writing - review \& editing

Thaiza Barreto: Methodology, Investigation, Writing - review \& editing

\section{REFERENCES}

ARAÚJO, A. R. R., BARBOSA, J. M., SANTOS, J. P., CARVALHO, B. L. F., GARCIOV FILHO, E. B., DEDA, M. S., SILVA, C. O. \& CHAMMAS, M. A. 2016. Boletim estatístico da pesca nos litorais de Sergipe e extremo norte da Bahia - 2014. São Cristóvão: Editora UFS.
BOOS, H., COSTA, R. C., SANTOS, R. A., DIAS-NETO, J., RODRIGUES, E. S., RODRIGUES, L. F., D'INCAO, F., IVO, C. T. C. \& COELHO, P. A. 2016. Avaliação dos camarões peneídeos (Decapoda: Penaeidae). In: PINHEIRO, M. \& BOOS, H. (eds.). Livro vermelho dos crustáceos do Brasil: avaliação 2010-2014. Porto Alegre: Sociedade Brasileira de Carcinologia.

CARVALHO SANTOS, R., PERROCA, J. F., COSTA, R. C. \& HIROSE, G. L. 2020. Population dynamics of Farfantepenaeus subtilis (Pérez-Farfante, 1967) and Litopenaeus schmitti (Burkenroad, 1936) (Decapoda: Penaeidae) and evidence of habitat partitioning in the northeast of Brazil. Regional Studies in Marine Science, 35, 101218. DOI: https://doi.org/10.1016/j. rsma.2020.101218

COSTA, R. C., FRANSOZO, A., MELO, G. A. S. \& FREIRE, F. A. M. 2003 Chave ilustrada para identificação dos camarões Dendrobranchiata do litoral norte do Estado de São Paulo, Brasil. Biota Neotropica, 3(1), 1-12.

DIAS-NETO, J. 2011. Proposta de Plano Nacional de Gestão para o uso sustentável de camarões marinhos do Brasil. Brasília: Instituto Brasileiro do Meio Ambiente e dos Recursos Naturais Renováveis.

FRANCO, A. C. N. P., SCHWARZ JUNIOR, R., PIERRI, N. \& SANTOS, G. C. 2009. Levantamento, sistematização e análise da legislação aplicada ao defeso da pesca de camarões para as regiões sudeste e sul do Brasil. Boletim do Instituto de Pesca, 35(4), 687-699.

FREIRE, K. M. F. \& ARAÚJO, A. R. R. 2016. Analysis of marine catches off the state of Sergipe (1950-2010). Arquivos de Ciências do Mar, 49(1), 13-29.

FREIRE, K. M. F. \& PAULY, D. 2005. Richness of common names of Brazilian marine fishes and its effect on catch statistics. Journal of Ethnobiology, 25(2), 279-296.

FREIRE, M. C. S., FREIRE, K. M. F., ROSA, L. C. \& BOMFIM, C. N. C. 2019. Estrutura populacional e morfometria do camarão branco Litopenaeus schmitti (Burkenroad, 1936) capturado pela pesca artesanal em Sergipe, Brasil. Tropical Oceanography, 47(1), 1-16.

FREIRE, K. M. F., ARAGÃO, J. A. N., ARAÚJO, A. R. R., ÁVILA-DA-SILVA, A. O., BISPO, M. C. S., VELASCO, G., CARNEIRO, M. H., GONÇALVES, F. D. S., KEUNECKE, K. A., MENDONÇA, J. T., MORO, P. S., MOTTA, F. S., OLAVO, G., PEZZUTO, P. R., SANTANA, R. F., SANTOS, R. A., TRINDADE-SANTOS, I., VASCONCELOS, J. A., VIANNA, M. \& DIVOVICH, E. 2015. Reconstruction of catch statistics for Brazilian marine waters (1950-2010). Fisheries Centre Research Reports, 23(4), 3-30.

IBAMA (Instituto Brasileiro do Meio Ambiente e dos Recursos Naturais Renováveis). 1997. Camarão do Nordeste. In: IBAMA 1997 (ed.). Lagosta, caranguejo-uçá e camarão do Nordeste: relatório das reuniões dos grupos permanentes de estudos (GPE). Brasília: Instituto Brasileiro do Meio Ambiente e dos Recursos Naturais Renováveis.

IBAMA (Instituto Brasileiro do Meio Ambiente e dos Recursos Naturais Renováveis). 2007. Estatística da Pesca. 2007. Grandes regiões e unidades da federação. Brasília: Instituto Brasileiro do Meio Ambiente e dos Recursos Naturais Renováveis.

MMA (Ministério do Meio Ambiente). 2004a. Instrução Normativa n 5 , de 21 de maio de 2004. Anexo Il. Lista nacional das espécies de invertebrados aquáticos e peixes sobreexplotadas ou ameçadas de sobreexplotação. Brasília: Ministério do Meio Ambiente. 
MMA (Ministério do Meio Ambiente). 2004b. Instrução Normativa $\mathrm{n}^{\circ} 14$, de 14 de outubro de 2004. Brasília: Ministério do Meio Ambiente.

MPA (Ministério da Pesca e Aquicultura). 2012. Boletim estatístico da pesca e aquicultura. Brasil 2010. Brasília: Ministério da Pesca e Aquicultura.

MPA (Ministério da Pesca e Aquicultura). undated a. Boletim estatistico da pesca e aquicultura. Brasil 2008-2009. Brasília: Ministério da Pesca e Aquicultura.

REIS JR., J. J. C., FREIRE, K. M. F., ROSA, L. C., BARRETO, T. M. R. R. \& PAULY, D. 2019. Population dynamics of Atlantic seabob Xiphopenaeus kroyeri (Decapoda: Penaeidae) off the state of Sergipe, northeastern Brazil. Journal of the Marine Biological Association of the United Kingdom, 99, 143-153.

SANTOS, C. R., SILVA, R. L. S., COSTA, C. R., DAVANSO, M. T. \& HIROSE, L. G. 2017. Evaluation of the management plan for penaeid shrimps in the continental shelf of Sergipe, Brazil. Boletim do Instituto de Pesca, 43(3), 308-321.

TEIXEIRA, E. C., SILVA, V. E. L., FABRÉ, N. N. \& BATISTA, V. S. 2020. Marine shrimp fisheries research-a mismatch on spatial and thematic needs. Scientometrics, 122(1), 591-606.
TEODORO, S. S. A., TEROSSI, M., MANTELATTO, F. L. \& COSTA, R. C. 2016. Discordance in the identification of juvenile pink shrimp (Farfantepenaeus brasiliensis and F. paulensis: Family Penaeidae): an integrative approach using morphology, morphometry and barcoding. Fisheries Research, 183, 244-253.

THOMÉ-SOUZA, M. J. F., DANTAS JUNIOR, J. F., SILVA, F. C. B., FÉLIX, D. C. F. \& SANTOS, J. C. 2012. Estatística pesqueira da costa do estado de Sergipe e extremo norte da Bahia 2010. São Cristóvão: Editora UFS.

THOMÉ-SOUZA, M. J. F., DEDA, M. S., SANTOS, J. P., CARVALHO, B. L. F., ARAÚJO, M. L. G., GARCIOV FILHO, E. B., FÉLIX, D. C. F. \& SANTOS, J. C. 2013. Estatística pesqueira da costa do estado de Sergipe e extremo norte da Bahia 2011. São Cristóvão: Editora UFS.

THOMÉ-SOUZA, M. J. F., CARVALHO, B. L. F., SILVA, C. O., DEDA, M. S., GARCIOV FILHO, E. B., FÉLIX, D. C. F. \& SANTOS, J. C. 2014 a. Estatística pesqueira da costa do estado de Sergipe e extremo norte da Bahia 2012. São Cristóvão: Editora UFS.

THOMÉ-SOUZA, M. J. F., CARVALHO, B. L. F., GARCIOV FILHO, E. B., SILVA, C. O., DEDA, M. S., FÉLIX, D. C. F. \& SANTOS, J. C. 2014b. Estatística pesqueira da costa do estado de Sergipe e extremo norte da Bahia 2013. São Cristóvão: Editora UFS.

ZAR, J. H. 2010. Biostatistical analysis. Englewood Cliffs, New Jersey: Pearson Prentice Hall. 